\title{
In Use of Permeable Groin for Reducing Longshore Sediment Transport at Tanjung Bayang Beach of South Sulawesi
}

\author{
Hasdinar Umar ${ }^{\mathrm{a}, *}$, Sabaruddin Rahman ${ }^{\mathrm{b}}$, Chairul Paotonan ${ }^{\mathrm{c}}$, Ahmad Yasir Baeda ${ }^{\mathrm{d}}$ \\ ${ }^{a}$ Department of Coastal Engineering/Laboratory of Coastal Engineering, Faculty of Engineering, Universitas Hasanuddin. Email: hasdinar.umar@ gmail.com \\ ${ }^{b}$ Department of Coastal Engineering/Laboratory of Coastal Engineering, Faculty of Engineering, Universitas Hasanuddin. Email: sabarahman5 @ gmail.com \\ 'Department of Coastal Engineering/Laboratory of Coastal Engineering, Faculty of Engineering, Universitas Hasanuddin. Email: paotonan_ch@yahoo.com \\ ${ }^{\mathrm{d}}$ Department of Coastal Engineering/Laboratory of Coastal Engineering, Faculty of Engineering, Universitas Hasanuddin. Email: baedayasir@gmail.com
}

\begin{abstract}
Breaking wave near beaches is the main force to generate longshore currents, which moved the sediment at surrounding area. Due to its negative outcome, which are erosion and sedimentation, the need of longshore sediment transport analysis become very important. One of the tools for solving that problem is by using coastal protection structure such as permeable groin. Permeable groin may reduce the rate of longshore sediment transport respectively by changing the level of permeability of the groin itself. The objective of this research was to obtain analytical results of the longshore sediment transport reduction analysis by using permeable groins at Tanjung Bayang Beach of South Sulawesi. Reduction of sediment transport along the beach was analyzed by calculating reduction coefficient, which is the ratio between the longshore current before and after hitting the permeable groins. The result showed that with $40 \%$ of permeability, the groin can reduce longshore sediment transport at Tanjung Bayang Beach for almost 50\%; from $341.37 \times 10^{3} \mathrm{~m}^{3} / \mathrm{year}$ to $170.68 \times 10^{3} \mathrm{~m}^{3} / \mathrm{year}$.
\end{abstract}

Keywords: Permeable groin; reduction; sediment transport

\section{Introduction}

Erosion and sedimentation solemnly occurred on some beaches in Indonesia. For example, the erosion occurred in the beach of Teluk Segara Bengkulu City due to crib from the old port of Bengkulu [1]. The crib blocked the longshore sediment transport to the east. Junarsa [2] stated that the erosion occurred in Pantai Pasaruan Serang occurred due to the sediment transport. Umar [3] analyzed the longshore sediment transport at Glagah Beach, Central Java was 343,32,103 $\mathrm{m}^{3} /$ year (west direction). If permeable groins were used with density of piles groin $(p) 40 \%$ then it could reduce the longshore sediment transport up to 166.36.103 $\mathrm{m}^{3} /$ year. Reduction of longshore sediment transport can be determined using the parameter of reduction coefficient [3]. Groin was effectively as sediment traps in the longshore direction and coastal stability buildings at Teluk Penyu Beach. The pattern of coastal line change of Teluk Penyu Beach for 5 years (2014 - 2019) has accretion but tends to be stable with the same value of equal accretion and erosion that was equal to $421 \mathrm{~m}^{2}$ and
$408.56 \mathrm{~m}^{2}$ [4]. Suswanto [5] determined the critical points of erosion and arranged concept of erosion prevention which considered as a few alternatives of cost protection structure such as groin, breakwater and also recommendations needed to treat Teluk Penyu Beach comprehensively. The cross-shore sediment transport was dominant to the west and longshore sediment transport was to the south. It caused in Akkarena Beach having significant erosion, especially in the area around the estuary [6].

Problems that occured in Tanjung Bayang Beach were the large sedimentation in the upstream of the Jeneberang estuary then emptied at Tanjung Bayang Beach. To overcome the problem, the use of permeable groin as a controller of the longshore sediment transport, was proposed. This paper will discuss and analyze the reduction process of longshore sediment transport by using permeable groin at Tanjung Bayang Beach, South Sulawesi.

${ }^{*}$ Corresponding author. Tel.: +62-811-416-5078

Jalan Poros Malino km. 6, Bontomarannu

Gowa, Indonesia, 92171 


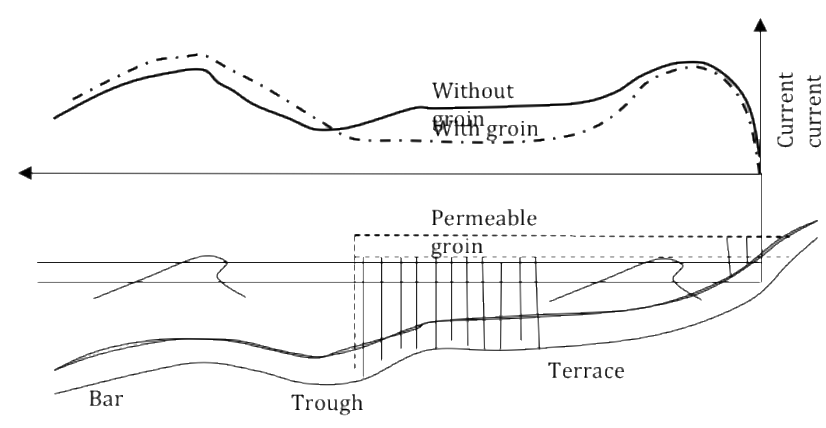

Figure 1. Beach profile after groin piles and alteration of longshore current [7]

\section{Permeable Groin}

The permeable groin has a split structure so that the longshore current can passed through the structure and the sediment can still be transported to the other side. The longshore currents and longshore sediment transport, which flowed through the permeable groins can be controlled by the gap density of the permeable groin structure itself. The widely used permeable groin was a piles groin, one of which was in Raudkivi [7] that examined the use of groin piles on the coast of Baltic Sea. Permeable groin used to reduce the longshore currents and longshore sediment transport but can still provide sediment supply to the other side of groin, which also called down drift groin. The longshore current reduction that occurs after the groin piles can be seen in Fig. 1.

\section{Longshore Sediment Transport}

The resulting movement of beach sediment along the coast is referred to as littoral transport or longshore sediment transport. In engineering application, the longshore sediment transport rate as the volume transport rate $Q_{l}$ having units such as $\mathrm{m}^{3} / \mathrm{day}$ or $\mathrm{m}^{3} /$ year. The equation of longshore sediment transport as a function of longshore current can be written as follows [8].

$$
Q_{l}=K \frac{\rho \sqrt{g / \gamma b}}{16\left(\rho_{s}-\rho\right)(1-n)} H_{b}^{2.5} \sin \alpha_{\mathrm{b}} \cos \alpha_{\mathrm{b}}
$$

with $Q_{l}$ is longshore sediment transport ( $\mathrm{m}^{3} /$ year), $K$ is empiric coefficient which affected by diameter of sediment grains $\left(D_{50}\right), K=1.4 e^{-2.5 D_{50}}, \rho$ is specific gravity of water/sea water $\left(\mathrm{kg} / \mathrm{m}^{3}\right), \rho_{s}$ is specific gravity of sediment $\left(\mathrm{kg} / \mathrm{m}^{3}\right), n$ is porosity of sediment $(n=0.4), H_{b}$ is breaking wave height $(\mathrm{m}), \alpha_{b}$ is breaking wave angle $\left({ }^{\circ}\right)$.

Longshore sediment transport is of particular importance inthat the transport can either be interrupted by the construction of jetties or groin (structure which block all or a portion of the longshore sediment transport), or can be captured by inlets and submarine canyons. If the beach uses the structure of permeable groin, then longshore sediment transport rate would be reduced, so the longshore

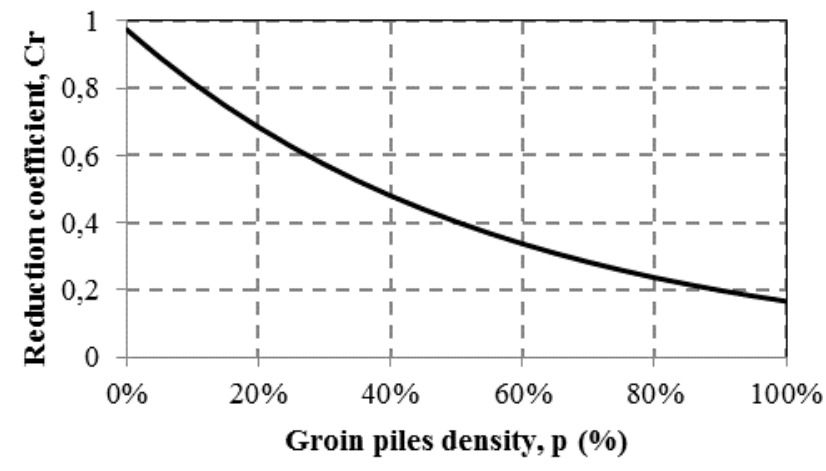

Figure 2. Relation between reduction coefficients $(\mathrm{Cr})$ with density of groin (p)

sediment transport rate after the permeable groin can be written as follows [3]

$$
Q_{l}=C_{r} K \frac{\rho \sqrt{g / \gamma b}}{16\left(\rho_{s}-\rho\right)(1-n)} H_{b}^{2.5} \sin \alpha_{\mathrm{b}} \cos \alpha_{\mathrm{b}}
$$

with $C_{r}$ is reduction coefficient, where the value of the reduction coefficient parameter depends on the density parameter of the groin piles.

\section{Reduction of Longshore Sediment Transport}

If the value of the average velocity of the longshore current after the permeable groin can be determined, the coefficient parameter of the longshore current velocity reduction $\left(C_{r}\right)$ can also be determined; which is the ratio between longshore current velocity after the instalment of permeable groin with longshore current velocity without any groin [3].

$$
C r=\frac{\langle v\rangle \text { groin }}{\langle v\rangle \text { without groin }}=\frac{1}{1+\frac{C_{d} p h r}{1.3 C_{f} d_{t}}}
$$

Equation (3) shows that the parameters of groin piles density affect the magnitude of the longshore current reduction coefficient. If it was illustrated the relationship between the reduction coefficient and the groin piles density, it shows that the greater percentage value of the groin piles density (the gap between the groins was getting denser), the smaller reduction coefficient will be (as in Fig. 2).

\section{Case Study of Tanjung Bayang Beach}

Tanjung Bayang Beach was located in the mouth of the Jeneberang river which was one of the major rivers in South Sulawesi that flows from Mount Bawakaraeng to Makassar strait and empties into the sea [9]. 
Table 1. Wave data

\begin{tabular}{cccc}
\hline Year & Hs $(\mathrm{m})$ & $\mathrm{Ts}(\mathrm{s})$ & Dir(deg.) \\
\hline 2007 & 1.8 & 7.18 & 265.26 \\
2008 & 1.13 & 5.64 & 275.92 \\
2009 & 1.08 & 5.59 & 273.62 \\
2010 & 0.85 & 5.48 & 279.43 \\
2011 & 2.45 & 7.57 & 267.11 \\
2012 & 1.36 & 6.18 & 270.14 \\
2013 & 2.01 & 7.71 & 280.15 \\
2014 & 0.83 & 6.25 & 269.37 \\
2015 & 0.64 & 7.07 & 272.96 \\
\hline
\end{tabular}

Table 2. Wave data based on return period

\begin{tabular}{ccc}
\hline $\begin{array}{c}\text { Return period } \\
\text { (year) }\end{array}$ & Hs (m) & Ts (s) \\
\hline 2 & 1.24 & 6.29 \\
5 & 1.94 & 7.88 \\
10 & 2.41 & 8.78 \\
25 & 3.00 & 9.80 \\
50 & 3.44 & 10.49 \\
100 & 3.88 & 11.13 \\
\hline
\end{tabular}

The wave data used in the analysis are the result of wind data analysis in Makassar waters from 2007 to 2015, as shown in Table 1.

Based on the wave data for the above years it could be said that the expected wave was equaled or exceeded once in a given year period, which was a wave with a return period that showed in Table 2 .

Based on the wave data then the calculation of longshore sediment transport can use the dominant direction of the wave from West, as shown in Fig. 3.

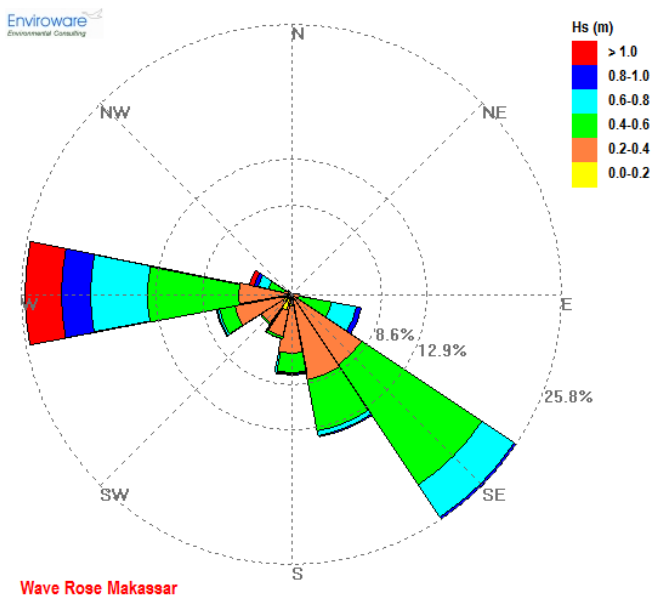

Figure 3. Wave rose of Tanjung Bayang beach

The image of the coastline position toward the wave direction is shown in Fig. 4. The calculation results wave analysis of Tanjung Bayang Beach is shown in Table 3.
Table 3. Wave parameter of Tanjung Bayang Beach

\begin{tabular}{ccccc}
\hline Direction & Return period & $\begin{array}{c}\mathrm{H}_{\mathrm{o}} \\
(\mathrm{m})\end{array}$ & $\begin{array}{c}\mathrm{H}_{\mathrm{b}} \\
(\mathrm{m})\end{array}$ & $\begin{array}{c}\alpha_{\mathrm{b}} \\
\left({ }^{\circ}\right)\end{array}$ \\
\cline { 2 - 3 } & 2 & 1.24 & 1.21 & 4.44 \\
West & 5 & 1.94 & 1.89 & 4.42 \\
$\alpha=45^{\circ}$ & 10 & 2.41 & 2.35 & 4.43 \\
& 25 & 3.00 & 2.93 & 4.42 \\
& 50 & 3.44 & 3.36 & 4.43 \\
& 100 & 3.88 & 3.79 & 4.43 \\
\hline
\end{tabular}

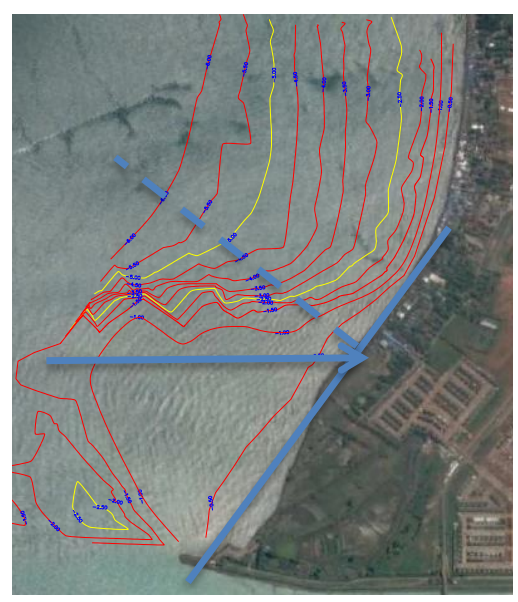

Figure 4. Location of study [10]

Table 4. Longshore sediment transport of Tanjung Bayang beach

\begin{tabular}{ccccccr}
\hline \multirow{2}{*}{ Dir } & \multirow{2}{*}{$\begin{array}{c}\text { Return } \\
\text { period }\end{array}$} & $\begin{array}{c}\text { Q } \\
\text { without groin } \\
\left(10^{3}\right.\end{array}$ & \multicolumn{4}{c}{$\begin{array}{c}\text { Q } \\
\left(10^{3} \mathrm{~m}^{3} / \text { yearle }\right.\end{array}$} \\
\cline { 4 - 7 } & $\mathrm{m}^{3} /$ year $)$ & $10 \%$ & $20 \%$ & $30 \%$ & $40 \%$ \\
\hline West & 2 & 341.37 & 273.1 & 238.96 & 204.82 & 170.68 \\
$\alpha=45^{\circ}$ & 5 & 1041.86 & 833.5 & 729.3 & 625.12 & 520.93 \\
& 10 & 1793.2 & 1435 & 1255.2 & 1075.9 & 896.59 \\
& 25 & 3097.63 & 2478 & 2168.3 & 1858.6 & 1548.8 \\
& 50 & 4364.74 & 3492 & 3055.3 & 2618.8 & 2182.4 \\
& 100 & 5908.41 & 4727 & 4135.9 & 3545 & 2954.2 \\
\hline
\end{tabular}

While the calculation results of longshore sediment transport at Tanjung Bayang beach before and after there are permeable groin is shown on Table 4 . Table 4 showed that with $10 \%$ permeability, the groin can reduce the longshore sediment transport up to $80 \%$; with $20 \%$ permeability can reduced up to $70 \%$ and so on until it can reach $50 \%$ reduction at $40 \%$ permeability. Raudkivi [6] said that with $50 \%$ reduction, beach stability can still be maintained in general. Table 3 also showed that from return period of 2 years until 100 years, if the groin can be maintaining its permeability at $40 \%$ and no big changes in structure nor changing climate of surroundings area, then the reduction of longshore sediment transport can also be maintained at approximately $50 \%$ respectively.

\section{Conclusion}

Based on the characteristics of Tanjung Bayang beach and the result analysis of longshore sediment transport reduction, it could be concluded that longshore sediment transport at Tanjung Bayang beach was $341,37.10^{3} \mathrm{~m}^{3} /$ year 
eastward (due to wave from the west) without the installment of permeable groin. But by using $40 \%$ of permeability or groin density, the longshore sedimentation transport at Tanjung Bayang beach can be reduced up to $170.68 \times 10^{3} \mathrm{~m}^{3} /$ year.

\section{Acknowledgements}

The authors would like to thank to LP2M Unhas for the grant of Maritime Indonesia Specific Continent (BMIS) 2017 and Coastal Engineering Laboratory, Coastal Engineering Department, Universitas Hasanuddin.

\section{References}

[1] Kesumajaya, (2005), Study of coastal erosion and sedimentation Teluk Segara District, Bengkulu City, Magister Tesis, ITB, Bandung.

[2] Junarsa. Dedi, (2006), Study of erosion and solving system at Pasauran Beach, Kabupaten Serang, Propinsi Banten, Magister Thesis ITB, Bandung.
[3] Umar, Hasdinar, (2016), Reduction of Longshore Sediment Transport, Enjiniring Journal, Fakultas Teknik Unhas, ISSN 14116243, Vol 20 No. 2, November 2016; page 82.

[4] Yustian. Aulia,and Nugroho, Denny, (2016), Groin Effectiveness Study on The Changes of Coastal Line at Teluk Penyu Beach, Cilacap, Oseanografi Journal, Vol 5, No. 3, 2016, page 406-414.

[5] Suswanto, B, (2017), Study of Coast Protection Structure in Teluk Penyu Beach as Supporting at The Waterfront City Concept in Tobali City South Bangka Regency, Master Theses, ITB, 2017.

[6] Munandar. F.A and Baeda. A.Y, (2014), Study of Sediment Transport at Akkarena Beach, Widyaiswara Network Journal, First Edition No. 1, Jan-Mar 2014.

[7] Raudkivi, (1996), Permeable Pile Groins, Journal of Waterway, Port, and Coastal Engineering, ASCE, 122 (6), pp 267-272.

[8] USACE, (2002), Coastal Engineering Manual, Washington, D.C.

[9] Langkoke, (2011), Coastal Morphodynamic and Prospect of Vegetation Distribution by Backshore Sediment: Estuary Jeneberang Makassar, Doctoral Dissertation.

[10] Anonim, (2012), Tanjung Bayang, Google earth, accessible year 2012. 